\title{
Issues Affecting Selection and Evaluation of ESP Teaching Materials
}

\author{
Magda Pašalića, Bisera Plančić
}

The paper will point out a range of obstacles and challenges English lecturers encounter when teaching English for Specific purposes (ESP) and when deciding which course book and teaching materials would best suit their students in tertiary education. Other issues relating to ESP will also be considered such as what exactly ESP means, main characteristics of ESP courses, their teachers and students. This paper will also include analysis of actions that need to be taken in the evaluation of ESP materials as suggested by various authors on the subject. There will be an example of the specific requirements of teaching materials in Maritime English and their evaluation. The aim is to give an overview of theoretical perspectives and methodologies for the evaluation of teaching materials and to encourage ESP teachers to design evaluation techniques for their type of ESP course.

\section{KEY WORDS}

$\sim$ ESP teaching materials

$\sim$ ESP course book evaluation

$\sim$ ESP teachers

$\sim$ Tertiary education

$\sim$ Maritime English

\section{INTRODUCTION}

In this paper the aim is to refer to some obstacles and issues that teachers of English for Specific Purposes (ESP) encounter when teaching ESP and when deciding upon which course book to use with their students in the tertiary institution. While analysing these problems other issues relating to ESP have also been considered, namely what exactly ESP means and what challenges its teachers and learners often have to face. The paper also includes evaluation procedures of ESP course books suggested by many subject matter experts.

ESP is without any doubt a prevailing approach to teaching English as a foreign language in higher education contexts. It is almost completely focused on the particular needs and language requirements of students of specific professional fields. Each ESP has its own characteristics and requirements and therefore, there are many varieties governed by specific needs. This paper offers an example of dealing with the problems of ESP teaching and textbook material evaluation in Maritime English which not only serves to prepare students for their future professions, but also plays a very important role in safety of life at sea.

Many would recommend needs analysis as a prerequisite for either developing a new ESP course or altering the current one. Furthermore, the fact that teaching materials may have a strong impact on students' motivation, teaching methods, vocabulary and language functions which will be taught in the ESP course cannot be ignored (Pranckevičiute \& Zajankaauskaite, 2012).

All ESP teachers start teaching ESP (Business English, Medical English, Maritime English, Legal English etc.) with, in most cases, quite scarce knowledge in the subject areas. Therefore, a solid course book is considered a helpful tool in the ESP classes. Riazi (Riazi, 2003 as cited in Baleghizadeh and Rahimi, 2011) claims that course books represent the second most 
important factor in foreign language classes, the first one being the teacher. What is more, course books provide teachers a basic structure for the course, a source of language and a support to learning. Besides, they encourage students' motivation ( $\mathrm{O}^{\prime} \mathrm{Neill}$, 1982; Dudley-Evans \& St John, 1998 as cited in Baleghizadeh and Rahimi, 2011).

\section{CHARACTERISTICS OF ESP COURSES}

What distinguishes an ESP course from English for General Purposes (EGP) course is that an EGP course mainly focuses on education while an ESP course focuses on training. In an ESP course, teachers may need methodology different from the one needed for an EGP course and the majority of ESP courses is designed for students who are at the intermediate or advanced levels of English knowledge (Anthony, 1998).

When considering an ESP course, it has to be designed for a specific group of learners who belong to a particular professional context. Hence, the teaching materials need to comply with this group's specific field of study and their future professional communities (Baleghizadeh and Rahimi, 2011; Hyland, 2002). It must be pointed out here that ESP is taught to adults not only at universities or other types of tertiary level institutions, but in-house as well although the needs of learners in these two contexts are to some extent different.

\subsection{Advantages of ESP Course Books}

ESP course books provide functional and grammatical references suitable for our students (O'Neill, 1982). They offer various ideas for discussions on topics relevant to students' future professions, definitions of complex terms or phrases and they in fact help ESP teachers with the direction their classes will have (Wisniewska, 2012). Beyond any doubt, course books should represent helpful tools for ESP teachers, particularly for the inexperienced ones. Additionally, they offer materials which help students recycle the contents of the units in the course books and in that way improve their learning abilities (Lubina, Kulenović and Lumezi, 2015).

O'Neill (1982) opted for using course books when he had to teach English to a group of German technicians because the course books he used at the time provided well-presented materials that enabled him to adapt his teaching and to improvise when he needed to encourage creative and spontaneous interactions among his learners.

Gatehouse (2001) emphasises that course books need to enable our students to be successful in work-related communication providing them with the ability to use the specialized jargon of a particular professional circle, the ability to employ a set of academic skills appropriate for the occupational setting under discussion and the ability to use the language of everyday informal talk to get engaged in effective communicational activities such as chatting over coffee with a colleague or responding to an informal e-mail message.

ESP course books should help teachers enable and encourage their students to become more independent learners and active participants in the learning process. A good course book contains progress checks which add to the self-study feature that has to be a characteristic of every ESP course book. Furthermore, very important features of ESP course books are authenticity and being up-to-date. An example for the comprehensive as well as teachers and learners-friendly ESP course books is a Market Leader (Cotton, Falvey and Kent, 2010, 2011, 2012) set of Business English course books which are designed based on authentic resources and in cooperation with Financial Times, the prominent journal dedicated to analysis of authentic business issues.

\section{HOW TO EVALUATE ESP COURSE BOOKS?}

The challenges of selecting an appropriate ESP course book can be rather frustrating sometimes. There are many of them available on the market and all of them published by wellknown, well-established publishers (one of them is mentioned in the previous chapter) which may help ESP teachers overcome the problem of selecting an appropriate course book. However, this may be true for the Business English or for the Academic English, but some ESP niche areas suffer from acute course book deprivation mostly for the lack of research and publishers' interest. ESP teachers need a course book that will provide authentic language and contexts but at the same time represent a methodologically well-structured resource that will serve as a solid study material for midterm tests or tests at the end of the ESP course. Moreover, ESP course books have to include authentic situations from the world of work relevant to particular studies and authentic materials relating to those situations which will help ESP teachers involve their students in communicative tasks or other simulations of real work-related situations.

Nunan (Nunan, 1991 as cited in Karimnia and Jafari 2017) emphasised the importance of teaching materials evaluation because it helps teachers select the most appropriate materials which cater for students' interests, needs as well as course programme goals. Furthermore, it is necessary to carefully analyse the contents and methodology of a course book.

Pritchard (2003:9) states that the most usual methods or means of evaluation, found in a number of authors, are the following:

$\begin{array}{ll}\text { - } & \text { questionnaires } \\ \text { - } & \text { rating scales } \\ \text { - } & \text { interviews } \\ \text { - } & \text { observation }\end{array}$


- discussion

- records

- assessment.

Most of the above mentioned methods are more appropriate for designing teaching materials for an ESP course. Not all of them are applicable for the tertiary teaching context because ESP teachers are the ones who choose the course book which will be prescribed as mandatory literature for an ESP course. In this context in many cases a course book serves as a syllabus, therefore, ESP teachers have to be particularly careful when deciding upon which course book to use with their students.

Hence, there are some useful questions teachers need to answer prior to choosing an appropriate textbook. Shave (2010), for instance, suggests the following questions:

- Will a particular course book provide the syllabus or there is a designed detailed syllabus?

- What are specific goals of the course?

- How long will the course last?

- What kinds of resources will be available in the classroom?

- How many students shall we teach? and

- How will the students' progress be measured?

Ellis (1997) points out that all checklists and guidelines designed for the evaluation of EFL course books are primarily instruments that can help English teachers perform a predictive course book assessment in a systematic way. The instruments, as he claims, are structured in a way which represents the decisionmaking process English teachers need to go through when carrying out an evaluation of course books.

Furthermore, McDonough and Shaw (McDonough and Shaw, 2003 as cited in Baleghizadeh and Rahimi, 2011:1010) offer three steps of evaluating course books. The first one they entitle external evaluation which includes analysis of the cover, introduction and table of contents. External evaluation provides ESP teachers with "the intended audience, the proficiency level, the context of use, presentation and organization of materials, and authors' opinion about language and methodology, use of audiovisual materials, vocabulary list and index, cultural aspects, tests and exercises included in the book." The second step refers to the internal evaluation i.e. assessment of the skills included in the course book, of how authentic listening and speaking materials are, of how appropriate tests and materials are and finding out if the course book can cater for different learning styles. The third step the authors name is the general evaluation of the materials i.e. evaluating "usability, generalizability, adaptability, and flexibility" of a particular course book.

Moreover, Shave (2010) designed a list of evaluation criteria used for assessment of course books. These criteria include the following issues:

- aims and approaches,

- language content,
- skills,

- topic and

- methodology.

Aims and approaches refer to the compatibility of course goals and aims of a course book, text adaptability, structure and design, language recycling and the level of user-friendliness. Language content requires evaluation of the authenticity of materials, vocabulary, pronunciation, suitable language covered, language styles and language which refers to more complex issues such as social norms. Skills would include assessment of suitability of reading, writing, listening and speaking activities. Topic is the criterion which emphasises the importance of evaluation of topics included in a course book. Here a teacher should answer questions such as: Are all topics suitable compared to the age, culture and social matters of the students s/he teaches? and Are the topics adaptable and sophisticated enough? The last criterion named is methodology. Issues evaluated here are: to what extent is a course book learnercentred; is the language used suitable; are approaches used congruous with your students' abilities; is structure and grammar presented acceptable and is attention drawn to study skills and learner autonomy.

It appears that many teachers of ESP do not carry out empirical evaluations of course books used or the ones they plan to use. Ellis (1997) suggests that there are fewer empirical evaluations carried out than impressionistic ones (when teachers evaluate if a certain activity "works" during the course). One of the main reasons for this, he claims, might be the fact that empirical evaluations are time-consuming. However, he proposes teachers conduct micro-evaluations which are easily manageable and less time-consuming. Micro-evaluations include an evaluation of a single task. In other words, teachers need to assess if aims of the task have been accomplished and if there is a need for improvement of the task (Alderson, 1992 as cited in Ellis, 1997). It might be a good idea, suggests Ellis further, that teachers prepare a report of evaluation procedure because in that way they can have a systematic and explicit description of the whole evaluation process.

\section{MARITIME ENGLISH}

English has been a lingua franca among seafarers for centuries expanding from the use of basic terminology in English to modern Maritime English that has been standardised by the International Maritime Organisation (IMO) and national legislation of each member state. It is taught at Universities in accordance with the requirements of the 1995 STCW (International Convention on Standards of Training, Certification and Watchkeeping for Seafarers), as amended (IMO, 2011), and Model Course 3.17. The model course for Maritime English presupposes that a very high level of General English (GE) is 
required in order to accomplish specific professional objectives. English for Academic Purposes and Business English are also large areas to be explored just as much as other ESP registers that go beyond general technical vocabulary. Maritime English encompasses the terminology of Ship Construction, Ship Handling, Navigation, Astronomy, Meteorology, Manoeuvring, Maintenance, Safety, Marine-Engineering, Business Economy, Transport, Medicine, Maritime Law, Insurance, not to mention very important role that GE plays in inter-cultural business and social communication on board the ship, and various shorebased companies and institutions.

Although Maritime English has the status of a mandatory, core subject within a specific education and training programme of seafarers, the real requirements go much higher. In his view of the standards and teaching of Maritime English, Pritchard (2002:11) points out that teachers should not only meet the minimum requirements of the IMO Convention but that:

"They should also carry out a thorough study of the needs analysis while at the same time examining technological, sociocultural, sociolinguistic, pragmatic and cognitive aspects of the language used at sea."

According to Pritchard deck and engineer officers need to be competent communicators in English and its specialised subset, Maritime English, in order to meet the shipping industry standards.

\subsection{Evaluation of Maritime English Course Books}

It was necessary to introduce these special features of Maritime English prior to addressing one of the main questions of this paper - how to select a proper course book and teaching materials for an ESP course. A comprehensive course book for Maritime English that would satisfy all above mentioned requirements is not available on the market and considering the complexity of the subject, we must admit that it would be quite impossible to produce one. The main reasons for limitations of available course books are stated by Pritchard (2003) in his articles "Survey of Maritime English Teaching Materials" and "A Databank of Maritime English resources - An invitation for contributions" (Pritchard, 2004:3):

"While in the field of English for General Purposes (EGP) there has been a wealth of published materials commercially available on the market, this has not been the case for Maritime English, a restricted subset of English for Specific Purposes (ESP). There seem to be a number of reasons for such a situation:

- non-existence of standards on Maritime English syllabus,

- lack of standards on Maritime English textbooks,

- unarticulated demand and, in turn, lack of interest on the publishers'side,

- poor supply of textbooks for international use,
- $\quad$ restrictive national legislations and language policies, and - slow adjustment of conventional textbooks to the developments in foreign language teaching and modern teaching technologies (cf. Pritchard, 2003:3)."

In his report on the evaluation of Maritime English teaching materials conducted under the auspices of IAMU (The International Association of Maritime Universities), Pritchard (2003) introduces the methods of the evaluation of materials that would later form the methodological basis for a web-based project on evaluation of the Maritime English database materials.

Pritchard (2003) states that there are two criteria for evaluating Maritime English teaching materials: external criteria that refer to extra-linguistic aspects of materials and internal criteria related to language.

We can see from Pritchard's "Survey of Maritime English Teaching Materials" that the most representative materials, available at that time, were analysed taking into consideration some of the most important theoretical views on materials evaluation by prominent scholars such as Sheldon, Robinson, Alderson, Moore, Griffiths, Tucker, Hutchinson and Waters, Shaw, Cunningsworth, Candlin and Breen, Ur, Littlejohn and others. Their questionnaire and checklist suggestions for EGP and ESP were studied and the final proposal for Maritime English textbooks was adapted from Sheldon (Pritchard 2003:81). The proposal includes a checklist that has 46 external factors for evaluation, and a questionnaire containing 26 questions (as in Supplement 1).

Although these and other evaluations of Maritime English teaching materials showed a great quality of presented materials, they also revealed the need for a comprehensive compilation of teaching materials as a databank of Maritime resources that would be made available for use to IMLA (International Maritime Lecturer's Association) and IMEC (International Maritime English Conference), Maritime English teachers and MET institutions worldwide. The goal of fulfilling this need has been achieved and there now is a database containing: "a digitalised list of textbooks, short course materials, videos, CD ROM and multimedia materials, software and internet resources for the various aspects of Maritime English. The web-based version of the databank also displays PDF format views of title pages, contents and sample units of individual materials." (Pritchard 2004:1).

In his paper "A Databank of Maritime English Resources - An Invitation for Contributions", Pritchard introduces potential users and contributors to the concept and structure of the Maritime English Resources Database and invites the teachers and learners of Maritime English to offer proposals for improvements, changes, corrections, and modifications of any kind. The teachers are also asked to contribute their own materials and take part in obtaining appropriate materials suitable to specific needs of both Maritime English teachers and learners. 


\section{ESP TEACHERS AND THEIR TRAINING}

At this point, the demands and challenges ESP teachers and practitioners have to face should be focused on since it is principally they who need to conduct evaluation and selection of ESP course books.

English instructors teaching an ESP course have a very demanding job, particularly at the beginning of their careers when they need to specialise in a field they knew nothing about prior to fulfilling that post. Bell (2002) points out that ESP practitioners have to be receptive to the specific field their ESP course focuses on. Furthermore, there are authors who support the idea that a team of English teachers and field specialists should teach the ESP course. However, some also point out the danger of field specialists monopolizing the contents and structure of an ESP course (Dudley-Evans, 1998).

On the other hand, when in doubt, ESP teachers should not hesitate to ask for suggestions and advice from their colleagues who are specialists in the field students study. These colleagues may offer specific textbooks and other materials that ESP teachers will use to prepare teaching materials for ESP classes (Falaus, 2016). ESP teachers usually acquire all the necessary knowledge from scratch by themselves as they usually come from Departments of English Language and Literature. At first, they are perplexed by the volume of material they do not understand. A similar view is presented by Hutchinson and Waters (1987:161), who argue that teachers trained for teaching General English may "feel a sense of utter inadequacy at their ability to cope" with highly specialised ESP materials. All things considered, ESP teachers have to face the situations in which they will become learners themselves (Medrea and Rus, 2012).

ESP teachers should not take a role of, as Robinson states it, "pseudo teacher(s) of subject matter" (Robinson, 1991 as cited in Belcher, 2006:140). However, teaching specific skills cannot be fully separated from teaching the subject these skills belong to (Hyland, 2002). We think that teachers should distance themselves from thorough explanations of the content subject matter and refer their students to specialists in those fields. Very often students have more knowledge on the subject being taught, but they need their teacher to assist them in expressing that knowledge.

Nonetheless, there is a lack of comprehensive references on ESP teacher development. There are, however, authors who proposed topics to be included in ESP teacher education, although with one downside and that is that empirical researches were not carried out (Master, 2005; Huttner, Smit and MehlmauerLarcher, 2009).

Maritime English teachers, fortunately, have many maritime associations that are at their disposal. For example, The World Maritime University (WMU) in Malmö, Sweden is a postgraduate maritime university founded in 1983 by the International Maritime
Organization (IMO), a specialized agency of the United Nations. They organize courses to upgrade the teaching competencies of those professionals involved in the delivery of Maritime English courses with the following learning outcomes:

- have become fully aware of what is required of the contemporary Maritime English teacher to fulfil at least the basic demands of IMO's legal instruments, its advisory Model Course 3.17 and IMO's Standard Marine Communication Phrases (SMCP), - have an understanding of the current methods being used, and knowledge of the resources available, in order to teach and assess Maritime English competencies,

- be in a position to develop and integrate the competencies discussed into the work situation, and share them with colleagues, and

- $\quad$ be prepared to embark upon a sustained process of selfdirected skills development.

ESP teachers need to remain open to continuous learning and keeping ahead of their students when it comes to the acquisition of intricate vocabulary items. This is in order for the teachers to be facilitators and help students in their efforts to become proficient in English both in professional and social settings. They have to be focused on their learners' needs and interests, often having to deal with large classes that are never homogenous when it comes to students' previous knowledge of GE which is essential in order to acquire the desired knowledge and skills. This considerably impacts on the choice of ESP teaching materials.

\section{CONCLUSION}

Issues analysed in this paper should be of importance to those teaching ESP in tertiary education. The overview and approaches investigated in the paper are supposed to draw attention and raise awareness of ESP teachers and trainers. Unquestionably, teaching ESP includes many demanding tasks for ESP teachers who need to invest a lot of time and effort in their education and professional growth. Learning how to evaluate ESP course books and materials is included in a wide range of those tasks. The authors of this paper have examined many articles discussing the issues regarding ESP teaching and evaluation of ESP course books and teaching materials, in order to help other ESP teachers interested in systematic and structured evaluation by means of checklists and questionnaires as well as some other methods.

ESP course books need to provide support in teaching and managing an ESP course. However, it appears that there are no ideal ESP course books and that ESP teachers may have to be prepared to design or look for supplement materials. On the other hand, evaluation techniques enable teachers to be creative and not to accept second-best, which may lower the efficiency of the ESP course thereby diminishing their efforts. Finally, it is 
understood that students need to be involved in the process of creating a base of material resources and most of the colleagues who are specialists in the subject area could contribute greatly with their expert pieces of advice.

\section{REFERENCES}

Anthony, L., 1998. Defining English for Specific Purposes and the Role of the ESP Practitioner. Available at: https://pdfs.semanticscholar.org/f5ee/81 c0e6984a5a5928 08b37a85dad82bac7da3.pdf, accessed on: April 132018.

Baleghizadeh, S. \& Rahimi, A.H., 2011. Evaluation of an ESP Textbook for the Students of Sociology. Journal of Language Teaching and Research, 2(5), pp. 10091014. Available at: http://dx.doi.org/10.4304/jttr.2.5.1009-1014.

Belcher, D.D., 2006. English for Specific Purposes: Teaching to Perceived Needs and Imagined Futures in Worlds of Work, Study, and Everyday Life. TESOL Quarterly, 40(1), pp. 133-156. Available at: http://dx.doi.org/10.2307/40264514.

Bell, D., 2002. Help! I've been asked to teach a class on ESP. IATEFL Newsletter, 169.

Cole, C., Pritchard, B. and Trenkner, P., 2007. Maritime English instruction - ensuring instructor's competence. Iberica, Rivista de la Associacion Europea de Lenguas Para Fines Especificos, 14, pp. 123-148.

Cotton, D., Falvey, D. and Kent, S., 2010. Intermediate Market Leader Business English Course Book. Harlow: Pearson Education Limited.

Cotton, D., Falvey, D. and Kent, S., 2011. Upper Intermediate Market Leader Business English Course Book. Harlow: Pearson Education Limited.

Cotton, D., Falvey, D. and Kent, S., 2012. Pre-intermediate Market Leader Business English Course Book. Harlow: Pearson Education Limited.

Ellis, M. and Johnson, C., 1994. Teaching Business English. Oxford: Oxford University Press.

Ellis, R., 1997. The empirical evaluation of language teaching materials. ELT Journal, 51(1), pp.36-42. Available at: http://dx.doi.org/10.1093/elt/51.1.36.

Fălăuş, A., 2017. The current challenges of teaching ESP. IOP Conference Series: Materials Science and Engineering, 200, p.012059. Available at: http://dx.doi.org/10.1088/1757-899x/200/1/012059.

Gatehouse, K., 2001. Key Issues in English for Specific Purposes (ESP) Curriculum Development. The Internet TESL Journal VII(10). Available at: http:/iteslj.org/ Articles/Gatehouse-ESP.html.

Hutchinson, T. \& Waters, A., 1987. English for Specific Purposes. Cambridge: Cambridge University Press. Available at: http://dx.doi.org/10.1017/cbo9780511733031.
Hyland, K., 2002. Specificity revisited: how far should we go now? English for Specific Purposes, 21(4), pp.385-395. Available at: http://dx.doi.org/10.1016/s0889-4906(01)00028-x.

Karimnia, A. \& Jafari, F.M., 2017. Critical ESP Textbook Evaluation: The Case of Visual Arts Textbook. Sustainable Multilingualism, 11(1), pp.219-236. Available at: http://dx.doi.org/10.1515/sm-2017-0020.

Lubina Lekaj, B., Kulenović Kiss, B. and Lumezi Linčir, M., 2015. Creating a business English coursebook for academic needs: challenges and solutions, Proc. 17th EBES Conference, Venice, Italy, October 15-17, pp. 1195-1210., available at: https://bib.irb. $\mathrm{hr} /$ datoteka/784297.CREATING_A_BUSINESS_ENGLISH_COURSEBOOK.doc.

Medrea, N. \& Rus, D., 2012. Challenges in Teaching ESP: Teaching Resources and Students' Needs. Procedia Economics and Finance, 3, pp. 1165-1169. Available at: http://dx.doi.org/10.1016/s2212-5671(12)00291-2.

O'Neill, R., 1982. Why use textbooks? ELT Journal, 36, pp. 104-111. Available at: http://textbookuse.pbworks.com/f/Why+use+textbooks.pdf.

Pranckevičiūtè, V. \& Zajankauskaite, Z., 2012. Adjusting an ESP Course to Students' Needs in Tertiary Education: a Case Study. Studies About Languages, 0(21). Available at: http://dx.doi.org/10.5755/j01.sal.0.21.2465.

Pritchard, B., 2002. On the Standards of Maritime English - Pedagogical implications. Proceedings of the Seminar on Maritime English - Istanbul 2002, Istanbul Technical University \& JICA. Available at: http://www.iamu-edu.org/report/1/pritchard.php

Pritchard, B., 2003. Maritime English syllabus for the modern seafarer: Safety-related or comprehensive courses? WMU Journal of Maritime Affairs, 2(2), pp.149-166. Available at:

http://dx.doi.org/10.1007/bf03195041.

Pritchard, B., 2004. A Databank Of Maritime English Resources: An Invitation For Contributions, Proceedings of 16th International Maritime English Conference- IMEC 16. Manila. Available at: https://www.researchgate.net/publication/228609435.

Pritchard, B., 2009. Survey of Maritime English Teaching Materials. Available at: http://www.imla.co/imec/BorisSurvey.pdf, accessed on: May 152018.

Pritchard, B., 2011. On Some Aspects of Mobility in Teaching Maritime English, Proc. 23rd International Maritime English Conference, Constanta Maritime University, Romania, October 10-14, pp. 5-16. Available at: http://www.pfri.uniri.hr/IMEC Proceedings/PDF/IMEC23.pdf.

Shave, J., 2010. A Teacher Friendly Process for Evaluating and Selecting ESL/EFL Coursebooks, The Internet TESL Journal, XVI(11). Available at: http://iteslj.org/ Articles/Shave-CourseBookEvaluation.html.

Wisniewska, H., 2012. Modern teaching materials: SWOT analysis of an ESP textbook. Available at: https://conference.pixel-online.net/conferences//edu_future/ common/download/Paper_pdf/ENT15-Wisniewska.pdf.

World Maritime University. Available at: https://www.wmu.se/professional/ maritime-english-\%E2\%80\%93-upgrading-teaching-competencies, accessed on: May 72018. 


\section{SUPPLEMENT}

CHECKLIST - EXTERNAL AND INTERNAL EVALUATION CRITERIA

Rating scale: 1 to 6 (where applicable)

\section{External Criteria:}

1. $\operatorname{AUTHOR(S):}$

2. TITLE:

3. PUBLISHER:YEAR:

4. ISBN: (total pages:)

5. TYPE (textbook, video, $C D$, software, supporting/back-up material)

6. COMPONENTS: SB/TB/WB/cassette/video/CD/free tests:

7. LENGTH (units $x$ hours):

8. TARGET LEARNERS:

9. TARGET SKILLS:

10. TARGET TEACHERS:

11. PURPOSE/RATIONALE (designed for the students of/trainees in ...)

12. AVAILABILITY (e.g. readily available)

13. LEVEL + USER DEFINITION (beginners, lower-intermediate, intermediate, upperintermediate, advanced)

14. LAYOUT/GRAPHICS (clear, attractive print, ...)

15. ACCESSIBILITY / ORGANISATION (arrangement of sections, parts, reading text, exercises, ...)

16. PHYSICAL CHARACTERISTICS (e.g. space to write notes, fill out exercises) (1-6)

17. SUPPLEMENT ARY MATERIALS (vocabulary, tables, additional reading, video, etc.)

18. CULTURAL BIAS (1-6) (meeting the requirements of multi- national/cultural/lingual crews/students; yes/no)

19. REFERENCE TO OTHER MATERIALS (maritime reference books, conventions, regulations, subject textbooks, ...)

20. GENERAL ASSESSMENT OF THE MATERIAL (in case of commercial materials) (rating: $1-6)$

OVERALL VALUE FOR MONEY (rating: 1 - 6)

DEGREE OF APPROPRIATNESS FOR A SPECIFIC COURSE (descriptive assessment: very high - high - medium - low)

\section{Internal Criteria:}

21. PURPOSE / OBJECTIVES - explained in introduction

22. APPROACH (acceptable to course curriculum, maritime authorities, maritime industry)

23. TYPE OF MARITIME ENGLISH (Comprehensive/General Maritime English, registeroriented, genre-oriented, spoken communication, ...)

24. THE NATURE OF LEARNING (content-based, skill-based, task-based, competencebased, ...)
Yes/No, Scalar Rating,

Description, Comment 
25. CONTENT PRESENTATION (systematic coverage of syllabus; topics covered)

26. ORGANISATION - layout (content clearly organized into units)

27. SEQUENCED GRADING OF CONTENT THEMES AND TOPICS

28. AUTHENTICITY (plenty of authentic language; modified texts)

29. COVERAGE OF SUBJECT CONTENTS (IN THE CURRICULUM)

30. GUIDANCE TO LEARNER (in introduction, units)

31. INTERESTING \& VARIED TOPICS \& TASKS (to provide for different learner levels, styles) $(1-6)$

32. DEVELOPMENT OF COMMUNICATIVE COMPETENCE: $(1$ - 6)

fluency in communicative functions: requests, asking questions, permission; possibility; probability; compulsion, obligation, prohibition, denial, negation)

33. SMCP-BASED TEXT \& EXERCISES (totally, partly, none)

34. PRONUNCIATION

35. THE FOUR SKILLS (LISTENING, READING, SPEAKING, WRITING) (Description of the methods, tasks, activities, and degree of communicative competence for each skill separately)

36. VOCABULARY DEVELOPMENT (1 - 6) (explanation and practice): terminology, multiword lexical units, EGP lexical items in specialized use

37. GRAMMAR (explanation and practice): (1 - 6) modals, tenses, passive; nominalizations, prepositional/adverbial phrases, syntax of complex sentences)

38. DISCOURSE ELEMENTS - TEXTUALITY (1 - 6) (discourse markers, coherence, cohesion)

39. EXERCISES $(1-6)$ (relevant, to-the-point, practicing)

40. SEQUENCED GRADING OF EXERCISES (1 - 6)

41. CLEAR INSTRUCTIONS for exercises (1 - 6)

42. KEY TO EXERCISES

43. SUPPLEMENTARY (VISUAL/AUDIO) MATERIALS AVAILABLE (audio cassette, video, CD, multi-media, software, etc.)

44. STUDENTS CAN DEVELOP OWN LEARNING STRATEGIES - INDEPENDENT LEARNING (1-6)

45. GUIDANCE TO TEACHER (adequate, not to heavy preparation load)

46. ASESSMENT (1 - 6) (in exercises, revision/review, final test)

ASSESSMENT (descriptive evaluation) 


\section{QUESTIONNAIRE}

1. Does the material match learner objectives? Is the purpose clearly defined?

Objectives explicitly laid out in an introduction, and implemented in the material

2. Is the material learner-centred? learners, learning styles, interests, etc.

3. Does the material facilitate interactive learning?

4. develops communicative skills

5. follows rules of content-based learning

6. follows cognitive procedures of the subject-matter (e.g. scripts and scenarios in ship handling, contingency planning; starting or reversing the main engine, etc.)

7. Is the material socio-culturally appropriate?

8. Is the material gender-sensitive?

9. How ethnocentric is the material?

10. CONTENT systematic coverage of syllabus. content clearly organized and graded (by difficulty)

11. Is the material up-to-date?

12. plenty of authentic language

13. Are instructions to students clear? clear instructions
14. Are vocabulary and comprehensible input levels wellgraded?

15. Is the material age-appropriate?

16. Is the material interesting and visually attractive? Is it interesting? Is it challenging? varied topics and tasks so as to provide for different

17. Is the material easy to use? Is the ratio of language given/ student task economic?

18. Does it contain distracting difficulties?

19. Is the material relevant to real life?

20. appropriate visual materials available

21. Does the exercise type effectively and economically accomplish purpose? periodic review and test sections

22. good pronunciation, vocabulary and grammar explanation and practice

23. fluency practice in all four skills

24. encourages learners to develop own learning strategies and to become independent in their learning

25. adequate guidance for the teacher

26. Does the material provide assessment: revision/reviews/ final?

(Adapted from Sheldon 1988:242 as cited in Pritchard, 2009) 